\title{
Sprawozdanie z konferencji naukowej z cyklu „Bogactwo polszczyzny w świetle jej historii” (Katowice, 7 listopada 2018)
}

\author{
A Report from the Cyclical Academic Conference \\ "The Richness of Polish Language in the Light of Its History" \\ (Katowice, 7 November 2018)
}

Dnia 7 listopada 2018 roku na Wydziale Filologicznym Uniwersytetu Śląskiego w Katowicach odbyła się ósma konferencja naukowa z cyklu „Bogactwo polszczyzny w świetle jej historii". Wydarzenie zostało zorganizowane przez Instytut Języka Polskiego im. Ireny Bajerowej Uniwersytetu Śląskiego w Katowicach. Referaty dotyczące szeroko pojmowanej historii języka polskiego wygłosili przedstawiciele z czterech polskich ośrodków akademickich: Katowic, Krakowa, Poznania i Warszawy.

Konferencję otworzyła dyrektor Instytutu Języka Polskiego im. Ireny Bajerowej - Mirosława Siuciak. Spotkanie naukowe zostało podzielone na trzy sekcje. Pierwsza z nich zawierała referaty profesorskie. Była to nowość w porównaniu do wcześniejszych konferencji, ponieważ dotąd brali $w$ nich udział tylko studenci, doktoranci i młodzi doktorzy. Jako pierwszy wystąpił Artur Rejter (Katowice), który poruszył problem wzajemnych relacji między językiem, historią i humanistyką oraz zwrócił uwagę na kwestię zbieżności historii języka i historii językoznawstwa. Następnie przedstawił mowę ludzką jako wielką tajemnicę (której zgłębianie nadal pozostaje niezwykle interesujące), a język - jako najbardziej „ludzki” (obok kultury) atrybut człowieka. W tym świetle humanistyka wydaje się dziedziną niemożliwą do przecenienia. Wystąpienie Aldony Skudrzyk (Katowice) stanowiło propozycję spojrzenia na współczesny stosunek do interpunkcji będący przejawem odchodzenia od piśmiennego stylu poznawczego. Prelegentka sygnalizowała, że odwrócenie kierunku zmian $w$ tekście pisanym od intelektualizacji (obecnej w tekstach w XIX wieku) do ponownej emocjonalizacji oraz mówioności, która wiąże się z „tu i teraz” mówienia, doświadczania i komunikowania, może być sygnałem kulturowej zmiany. Pierwszą sesję zamknął referat Katarzyny Wyrwas (Katowice) na temat jednostek leksykalnych odnoszących się do procesu wznoszenia budowli różnego typu. Prelegentka zaczerpnęła materiał językowy ze Słownika polszczyzny XVI wieku i porównała go ze słownictwem pochodzącym ze Słownika staropolskiego. Rozważania językowe zostały przedstawione na tle zmian w polskiej i europejskiej kulturze materialnej, technice budowlanej i stosunkach społecznych.

Kolejna sekcja obejmowała cztery referaty. Rozpoczęło ją wystąpienie Doroty Hamerlok (Katowice) dotyczące zmian semantycznych, którym ulegały na przestrzeni wieków

\footnotetext{
* e-mail: dorota.hamerlok@onet.pl
} 
nazwy osób przejawiających cechy choroby psychicznej. Autorka zwróciła również uwage na sposoby tworzenia nazw żeńskich osób upośledzonych umysłowo. Referat Wojciecha Stelmacha (Poznań) stanowił analizę szesnastowiecznego apokryfu staropolskiego Historyja barzo cudna o stworzeniu nieba i ziemie Krzysztofa Pussmana. Prelegent na podstawie badań komparatystycznych dowodził, że szesnastowieczne dzieło jest przekładem twórczym, a także przedstawił techniki tłumaczenia Krzysztofa Pussmana. Julia Piotrowska (Katowice) kontynuowała rozważania na temat rozwoju semantycznego leksyki polskiej. Referentka przyjrzała się konceptualizacji pojęcia posiadać na przestrzeni wieków, a dostrzeżone zmiany $w$ jego użyciu powiązała z rozwojem polszczyzny konsumpcyjnej. Sekcję zamykał referat Dominiki Kosteckiej (Warszawa), w którym przedstawione zostały nazwiska z ksiąg metrykalnych $w$ parafii Berżniki na terenie Sejneńszczyzny (pochodzące z okresu Księstwa Warszawskiego - od 1808 r.). Autorka zaproponowała klasyfikację tych nazwisk według kryterium semantycznego i skupiła się na wpływach wschodniosłowiańskich i bałtyckich.

Ostatnią, popołudniową sekcję, otworzył referat Beaty Kiszki-Pytel (Katowice), który dotyczył nazw własnych w poezji Jana Kasprowicza. Materiał badawczy został zaczerpnięty z cyklu sonetów Z chałupy i dwóch ostatnich tomów poety - Księgi ubogich i zbioru wierszy Mój świat. Autorka skupiła się na relacjach pomiędzy onimami odnoszącymi się do sfery religijnej i sfery handlowej oraz na wpływie tego typu nazw na interpretację tekstów Kasprowicza. Magdalena Błażejewska (Kraków) pokazała, w jaki sposób znajomość języka staro-cerkiewno-słowiańskiego może stać się ułatwieniem dla nauczyciela języka polskiego jako obcego, szczególnie w przypadku nauczania grup użytkowników języków słowiańskich. Za ilustrację stawianych tez posłużyły prelegentce procesy palatalizacji i metatezy. Referat Marii Zając (Katowice) został poświęcony składni dawnych tekstów naukowych z zakresu nauk humanistycznych. Materiał analityczny stanowiły artykuły językoznawcze (dotyczące historii języka) i pedagogiczne (z zakresu historii wychowania) z przełomu XIX i XX wieku. Autorka omówiła różnice i podobieństwa między nimi oraz czynniki, które wpływały na składniowe ukształtowanie danej publikacji. Jako ostatnia głos zabrała Aleksandra Mól (Katowice). Referentka zaproponowała definicję gatunku przysięgi i umiejscowiła go wśród realizacji stylu urzędowego. Wskazała także najbardziej charakterystyczne cechy omawianego gatunku.

Atut konferencji stanowiła różnorodność tematyczna i metodologiczna prezentowanych wystąpień. Owocna dyskusja po każdej sekcji dowodzi, że historia języka polskiego jest zagadnieniem niezmiennie interesującym, także dla młodych badaczy. Spotkanie naukowe umożliwiło postawienie pytań, na które uczestnicy konferencji będą próbowali odpowiedzieć poprzez kontynuację swoich badań. Referaty wygłoszone w trakcie poprzednich spotkań złożyły się na siedem tomów pokonferencyjnych z cyklu Bogactwo polszczyzny $w$ świetle jej historii, wydanych w Katowicach. Omówione wystąpienia utworzą kolejny, ósmy tom tej serii. 